\title{
Hypersecretion of anti-diuretic hormone due to tuberculous meningitis
}

\author{
JOLLYON SMITH \\ M.B., M.R.C.P.
}

\author{
RICHARD GODWIN-AUSTEN \\ M.D., F.R.C.P.
}

\author{
Department of Neurology, Derbyshire Royal Infirmary
}

\begin{abstract}
Summary
Three patients with tuberculous meningitis complicated by hypersecretion of anti-diuretic hormone are described. The recognition of this complication is important in the treatment and prognosis of tuberculous meningitis.
\end{abstract}

\section{Introduction}

Although hypersecretion of anti-diuretic hormone (ADH) is a recognized complication of tuberculous meningitis (Stead, 1974) little emphasis has been given to this facet of the disease in recent reviews of the subject (Udani, Parekh and Dastur, 1971; Kocen, 1977). Three recent cases of tuberculous meningitis have been seen and hypersecretion of ADH was present in all. The associated fluid and electrolyte abnormalities contributed significantly to the clinical features, and treatment directed to the correction of these abnormalities was important in the recovery of one of the patients. It is wished to report these cases in order to emphasize the importance of recognizing and treating this complication of tuberculous meningitis.

\section{Case 1}

A 30-year-old man admitted with 4 weeks' progressive history of backache, weakness of the legs, meningism and left sixth nerve palsy. He was fully conscious and orientated on admission, but became stuporose $48 \mathrm{hr}$ later. The cerebrospinal fluid (CSF) contained: leucocytes $612 / \mu 1(60 \%$ lymphocytes), protein $6.0 \mathrm{~g} / 1$, glucose $0.5 \mathrm{mmol} / \mathrm{l}$, chloride $93 \mathrm{mmol} / \mathrm{l}$. No tubercle bacilli were seen in the Ziehl-Nielsen preparation, but Mycobacterium tuberculosis was cultured later. The chest X-ray showed a miliary pattern throughout both lungs. Initial plasma electrolytes are shown in Table 1.

Three weeks after admission the plasma arginine vasopressin (AVP) concentration was $22.4 \mathrm{pmol} / 1$ (inappropriately high for the serum osmolality of $255 \mathrm{mosmol} / \mathrm{kg}$ ). The alterations in fluid balance produced by fluid restriction and demeclocycline treatment are shown in Fig. 1, with further AVP levels.

Anti-tuberculous treatment (oral isoniazid and rifampicin, intramuscular and intrathecal streptomycin) was started $24 \mathrm{hr}$ after admission. Stupor persisted for 3 weeks, followed by a period of gross short-term memory impairment (Korsakow mental state). There was ultimate recovery of mental function.

\section{Case 2}

A 35-year-old woman was admitted with a 12-day history of meningism, vomiting and blurred vision. She was fully conscious and orientated on admission, but became comatose $24 \mathrm{hr}$ later. The CSF contained scanty acid and alcohol fast bacilli, and leucocytes $90 / \mu l$ ( $80 \%$ lymphocytes), protein $1.4 \mathrm{~g} / \mathrm{l}$, glucose less than $0.5 \mathrm{mmol} / \mathrm{l}$, and chloride $90 \mathrm{mmol} / \mathrm{l}$. There was hyponatraemia with low serum osmolality and high urine osmolality (Table 1).

Eight days after admission the plasma AVP assay was $18.3 \mathrm{pmol} / 1$ (inappropriately high for the serum osmolality of $270 \mathrm{mosmol} / \mathrm{kg}$ ). Fluid intake was restricted to less than 1.5 litre/day for 7 days, and demeclocycline given in a dose of $600 \mathrm{mg}$ daily for 3 days; this caused the plasma sodium concentration to rise to $142 \mathrm{mmol} / 1$, and the serum osmolality rose to $292 \mathrm{mosmol} / \mathrm{l}$.

Anti-tuberculous treatment was used as in Case 1 , but she remained unconscious, and died 5 weeks after admission. Post-mortem examination showed tuberculous meningitis with patchy infarction associated with arteritis and necrosis of small vessels. The posterior pituitary appeared normal. Histological examination confirmed the widespread infarction which, however, appeared to spare the hypothalamus. The main nuclear groups in the hypothalamus including the periventricular and supra-optic nuclei were identified and appeared normal. 
TABLE 1. Details of 3 patients with tuberculous meningitis

\begin{tabular}{|c|c|c|c|c|c|c|c|c|c|c|c|}
\hline \multirow[b]{2}{*}{ Case } & \multirow[b]{2}{*}{$\begin{array}{c}\text { Age } \\
\text { (years) }\end{array}$} & \multirow{2}{*}{$\begin{array}{l}\text { Duration } \\
\text { of illness } \\
\text { before } \\
\text { admission }\end{array}$} & \multirow{2}{*}{$\begin{array}{c}\text { Level of } \\
\text { consciousness } \\
\text { on } \\
\text { admission }\end{array}$} & \multirow{2}{*}{$\begin{array}{c}\text { Blood } \\
\text { pressure } \\
(\mathrm{mmHg})\end{array}$} & \multicolumn{5}{|c|}{ Plasma } & \multirow{2}{*}{$\begin{array}{c}\text { Urine } \\
\text { osmolality } \\
(\mathrm{mosmol} / \mathrm{kg})\end{array}$} & \multirow{2}{*}{$\begin{array}{r}\text { CSF. } \\
\text { Chlori费 } \\
\text { (mmolph) }\end{array}$} \\
\hline & & & & & $\begin{array}{c}\mathrm{Na} \\
(\mathrm{mmol} / \mathrm{l})\end{array}$ & $\begin{array}{c}\mathrm{Cl} \\
(\mathrm{mmol} / \mathrm{l})\end{array}$ & $\begin{array}{c}\mathrm{K} \\
(\mathrm{mmol} / \mathrm{l})\end{array}$ & $\begin{array}{c}\text { Urea } \\
(\mathrm{mmol} / \mathrm{l})\end{array}$ & $\begin{array}{c}\text { Osmolality } \\
(\mathrm{mosmol} / \mathrm{kg})\end{array}$ & & \\
\hline 1 & 32 & 4 weeks & $\begin{array}{l}\text { Normal } \\
\text { (stupor } \\
48 \mathrm{hr} \\
\text { later) }\end{array}$ & $180 / 130$ & 126 & 83 & $4 \cdot 2$ & $7 \cdot 2$ & 249 & 868 & 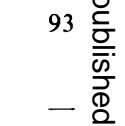 \\
\hline 2 & 35 & 12 days & $\begin{array}{l}\text { Normal } \\
\text { (coma } \\
24 \mathrm{hr} \\
\text { later) }\end{array}$ & $130 / 80$ & 126 & 92 & $3 \cdot 3$ & $2 \cdot 8$ & 249 & 502 & 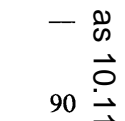 \\
\hline 3 & 30 & 6 weeks & Coma & $160 / 120$ & 126 & 88 & $3 \cdot 5$ & $\begin{array}{r}4.9 \\
- \\
\end{array}$ & $\begin{array}{r}270 \\
- \\
\end{array}$ & $\begin{array}{r}550 \\
-\end{array}$ & $-\vec{\omega}$ \\
\hline
\end{tabular}

Two sets of figures are given for plasma, electrolytes, etc.: the upper set of figures were those on admission, the lower, those 5 da्ds later.

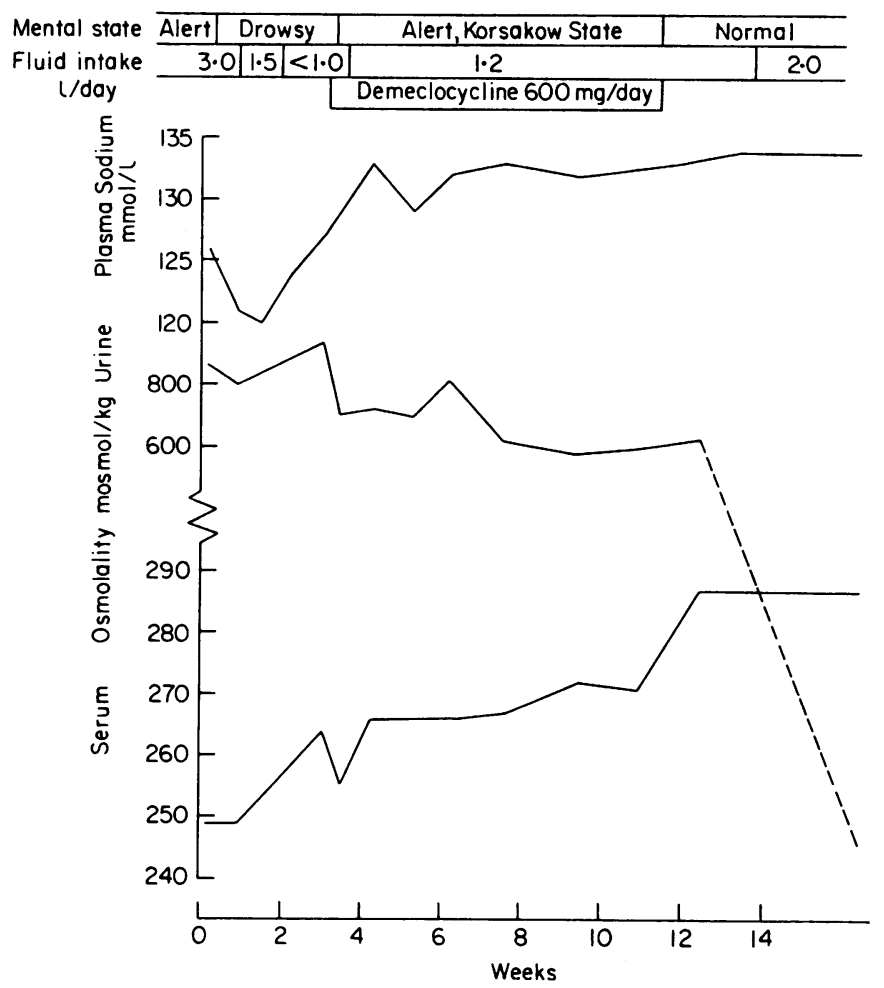

Fig. 1. The clinical course, plasma sodium, urine and serum osmolalities in Case 1.

\section{Case 3}

A 30-year-old man was admitted in coma (duration $24 \mathrm{hr}$ ). The CSF contained leucocytes $190 / \mu \mathrm{l}$ $(90 \%$ lymphocytes), protein $3.0 \mathrm{~g} / 1$, glucose $5 \cdot 2$ $\mathrm{mmol} / \mathrm{l}$. The CSF chloride was not measured. No tubercle bacilli were seen in the CSF. There was hyponatraemia with low serum osmolality; other details are given in Table 1 . In spite of anti-tuberculous treatment as in Case 1, he deteriorated rapidly and died $36 \mathrm{hr}$ after admission.

Post-mortem examination showed a tuberculoma of the choroid plexus giving rise to a tuberculous ventriculitis and meningitis. The posterior pituitary appeared normal. Sections through the hypothalamus showed that the periventricular nucleus was damaged by patchy subependymal necrosis. 
The main nuclear groups in the hypothalamus were identified including the supraoptic and paraventricular nuclei and appeared normal.

\section{Discussion}

The 3 patients described here all had tuberculous meningitis with hyponatraemia and hypochloraemia. Hypersecretion of ADH was suggested by the presence in all cases of low serum osmolality, high urine osmolality, with normal renal and adrenal function and no evidence of cardiac failure or fluid depletion (Bartter and Schwartz, 1967). A sensitive and specific radioimmunoassay (Baylis and Heath, 1977) confirmed the presence of high circulating levels of AVP in Cases 1 and 2.

In the 2 post-mortem cases there was little or no damage to the hypothalamus, and it therefore seems unlikely that the excessive production of $\mathrm{ADH}$ resulted from any direct involvement of the hypothalamus in the pathological process. However, AVP may be released as the result of a non-specific stress reaction from an intact hypothalamuspituitary axis (Schrier, 1974) and may therefore account for the hypersecretion of AVP in these cases. Inappropriate $\mathrm{ADH}$ has also been reported in pulmonary tuberculosis (Weiss and Katz, 1965) and in miliary tuberculosis without meningitis (Cockroft et al., 1976). It is therefore possible that in Case 1, who had miliary tuberculosis in addition to meningitis, an anti-diuretic substance may have been secreted from affected tissues other than the hypothalamus. Such a substance has been extracted from tuberculous granulomata (Vorherr, Massry and Fallett, 1970).

In the first 2 patients described here the CSF chloride concentration was low (CSF chloride was not estimated in Case 3), and this has been regarded as an almost constant finding in tuberculous meningitis (Merritt and Fremont-Smith, 1935; Ingham, 1937). Fremont-Smith et al. (1931) found that the low CSF chloride level in tuberculous meningitis followed directly from the fall in plasma chloride concentration. However, in the absence of chloride loss by vomiting, the low plasma chloride level is the result of water retention, the total body chloride remaining normal (Cheek, 1954). Profuse vomiting lowers the plasma chloride level still further, even in the presence of dehydration and hypernatraemia (Parekh, Udani and Panvalkar, 1972).

In Cases 1 and 2 an abrupt deterioration in level of consciousness was associated with a fall in plasma sodium concentration to $120 \mathrm{mmol} / \mathrm{l}$ and 121 $\mathrm{mmol} / \mathrm{l}$ respectively. Fluid retention and hyponatraemia may therefore have contributed to the impairment of consciousness, and in Case 1 improvement in level of consciousness coincided with a rise in plasma sodium concentration to $133 \mathrm{mmol} / \mathrm{l}$ (Fig. 1). However, hyponatraemia may be symptomless if the plasma sodium remains above $120 \mathrm{mmol} / \mathrm{l}$ (De Troyer and Demanet, 1976). It is therefore probable that changes in level of consciousness in the 3 patients were not caused solely by changes in fluid balance. In particular, in Case 2, extensive cerebral infarction led to continuing coma, long after the plasma sodium and osmolality had returned to normal. Nevertheless, treatment of the fluid retention and hyponatraemia may be important in tuberculous meningitis, particularly if the plasma sodium falls below $120 \mathrm{mmol} / \mathrm{l}$.

Correction of hyponatraemia caused by inappropriate ADH secretion cannot be achieved by administration of saline: in spite of hyponatraemia and hypochloraemia, renal sodium and chloride excretion continues in proportion to intake (Rapoport, West and Brodsky, 1951). Restriction of fluid intake prevents the progression of hyponatraemia seen with usual levels of fluid intake (Bartter and Schwartz, 1967). The tetracycline derivative, demeclocycline, inhibits the renal effects of $A D H$, and has been used in the treatment of water retention due to inappropriate ADH secretion (Singer and Rotenberg, 1973; Perks, Mohr and Liversedge, 1976). Both fluid restriction and demeclocycline were used in the treatment of Cases 1 and 2, with rapid restoration of normal fluid and electrolyte balance in Case 2, and a slower return to normality in Case 1 (Fig. 1).

The recognition and treatment of this complication is important in the management of patients with tuberculous meningitis. An early return of consciousness after correction of plasma osmolality may be a good prognostic sign in this condition.

\section{Acknowledgment}

We wish to acknowledge with thanks Dr P.H. Baylis for measuring the plasma AVP in our cases; also Dr D.A. Howell for the carrying out the post-mortem examinations.

\section{References}

BartTer, F.C. \& Schwartz, W.B. (1967) The syndrome of inappropriate secretion of antidiuretic hormone. American Journal of Medicine, 42, 790.

Baylis, P.H. \& Heath, D.A. (1977) The development of a radioimmunoassay for the measurement of human plasma arginine vasopressin. Clinical Endocrinology, 7, 91 .

CheEK, D.B. (1954) Total body chloride in tuberculous meningitis. Pediatrics, 14, 87.

Cockroft, D.W., Donevan, R.E., Copland, G.M. \& IBBOTT, J.W. (1976) Miliary tuberculosis presenting with hyponatremia and thrombocytopenia. Canadian Medical Association Journal, 115, 871.

De Troyer, A. \& Demanet, J.C. (1976) Clinical, biological and pathogenic features of the syndrome of inappropriate secretion of antidiuretic hormone. Quarterly Journal of Medicine, 45, 521. 
Fremont-Smith, F., Dailey, M.E., Merritt, H.H. \& CARroll, M.P. (1931). The equilibrium between cerebrospinal fluid and blood plasma; composition of human cerebrospinal fluid and blood plasma in meningitis. Archives of Neurology and Psychiatry. Chicago, 25, 1290.

INGHAM, J. (1937) Sodium chloride content of the cerebrospinal fluid in tuberculous meningitis. British Medical Journal, 2, 111.

Kocen, R.S. (1977) Tuberculous meningitis. British Journal of Hospital Medicine, 18, 436.

Merritt, H.H. \& Fremont-Smith, F. (1935) Cerebrospinal fluid in tuberculous meningitis. Archives of Neurology and Psychiatry. Chicago, 33, 516.

Parekh, U.C., Udani, P.M. \& Panvalkar, R.S. (1972) Serum electrolytes in tuberculous meningitis. Indian Pediatrics, 9, 354.

Perks, W.H., Mohr, P. \& Liversedge, L.A. (1976) Demeclocycline in inappropriate ADH syndrome. Lancet, ii, 1414.

RAPOPORT, S., WeST, C.D. \& BRODSKY, W.A. (1951) Salt losing conditions: the renal defect in tuberculous meningitis. Journal of Laboratory and Clinical Medicine, 37, 550.
SCHRIER, R.W. (1974) 'Inappropriate' versus 'appropriate' antidiuretic hormone secretion. Western Medical Journal, $121,62$.

Singer, I. \& RotenberG, D. (1973) Demeclocycline-induced nephrogenic diabetes insipidus. Annals of Internal Medicine, 79, 679.

Stead, W. (1974) Tuberculosis. In: Harrison's Principles of Internal Medicine (Ed. by Wintrobe, M.M., Thorn, G.W., Adams, R.D., Braunwald, E., Isselbacher, K.J. and Petersdorf, R.G.) 7th Edn, p. 865. McGraw Hill, New York.

Udani, P.M., Parekh, U.C. \& Dastur, D.K. (1971) Neurological and related syndromes in CNS tuberculosis. Journal of the Neurological Sciences, 14, 341.

Vorherr, H., Massry, S.G. \& Fallett, R. (1970) Antidiuretic principle in tuberculous lung tissue of a patient with pulmonary tuberculosis and hyponatremia. Annals of Internal Medicine, 72, 383.

WeISS, H. \& KATZ, S. (1965) Hyponatremia resulting from apparently inappropriate secretion of antidiuretic hormone in patients with pulmonary tuberculosis. American Review of Respiratory Diseases, 92, 609. 